\title{
ENVIRONMENTAL DISCLOSURE PRACTICE IN THE SERBIAN BANKING SECTOR
}

\author{
Aida Hanić* \\ Olivera Jovanović ** \\ Slavica Stevanović ***
}

Received: 5. 4. 2021

Preliminary communication

Accepted: 9. 7. 2021

UDC 336.71:502](497.11)

DOI https://doi.org/10.30924/mjcmi.26.2.7

\begin{abstract}
This paper aims to: a) analyse the environmental disclosure practice in the Serbian banking sector, b) determine whether the degree of disclosure is higher in the case of big, i.e. systemically important banks, and c) examine if there is a positive relationship between the banks' CSR practice and their financial performance. The environmental disclosure index (EDI) based on 15 variables was employed to measure environmental disclosure performance for the Serbian banking industry. The data were generated through content analysis of the annual and sustainability reports of a total of 10 banks, five of which were classified as systemically important banks for the period 2015-2019. The sample was determined by the availability of reports for the analysed period and the bank establishment year. The results show that the majority of Serbian banks discloses their environmental policy (74\%), the undertaken
\end{abstract}

Abstract

\section{INTRODUCTION}

Due to increasingly unfavourable climate changes that the world has been witnessing, the environment started to be analysed as one of the company's stakeholders (Dragomir, 2010). Research discourse in environmental activities with the local community $(51 \%)$, and the utilization efficiency of water, energy, and paper (48\%). Although the findings indicate that the environmental disclosure practice among all banks in Serbia is growing, the reports are not standardized. In addition, the systemically important banks in Serbia do not have a better disclosure practice. The econometric analysis implies that the bank's status does not influence the level of environmental disclosure and that there is no positive relationship between financial performance (ROA and ROE) and EDI. This study has implications for policymakers and accounting bodies in Serbia in standardizing non-financial reporting and creating certain green and sustainable banking guidelines.

Keywords: environmental disclosure, banking sector, content analysis, Serbia

this area has been particularly emphasized in the context of corporate social responsibility (CSR), where such an understanding of environmental issues has resulted in different terms used in the research context: Social Environmental Responsibility

\footnotetext{
* Aida Hanić, PhD, Research Assistant, Institute of Economic Sciences, Belgrade, Zmaj Jovina 12, 11000 Belgrade, Serbia, Phone: +381112623055, E-mail: aida.hanic@ien.bg.ac.rs, ORCID: https://orcid.org/0000-00034378-7002

** Olivera Jovanović, MA, Research Assistant, Institute of Economic Sciences, Belgrade, Zmaj Jovina 12, 11000 Belgrade, Serbia, Phone: +381112623055, E-mail: olivera.jovanovic@ien.bg.ac.rs, ORCID: https://orcid. org/0000-0002-0676-4787

${ }^{* * *}$ Slavica Stevanović, PhD, Research Associate, Institute of Economic Sciences, Belgrade, Zmaj Jovina 12, 11000 Belgrade, Serbia, Phone: +381112623055, E-mail: slavica.stevanovic@ien.bg.ac.rs, ORCID: https://orcid. org/0000-0002-8545-4540
} 


\section{Journal of Contemporary Management Issues}

(Edgar et al., 2002; Baughn et al., 2007); Environmental Corporate Social Responsibility (Bansal and Roth, 2000; Williamson et al., 2006; Abdul Rashid et al., 2015) or climate-related disclosure (Folger-Laronde and Weber, 2018). This approach emphasizes that the environment is not to be viewed exclusively as a CSR component but as a separate research topic (Harte and Owen, 1991). In such a relation, CSR communication with an adequate degree of disclosure stands out.

Disclosure practice is present in all sectors, but the degree of its implementation varies among industries. For instance, although the banking industry has an expressive social impact and establishes new trends and strategies (Platonova et al., 2016), social responsibility research gained much later application in this sector (Branco and Rodrigues, 2006; Krasodomska, 2015; Kilic, 2015; Matuszak et al., 2019). According to the literature review by Aracil et al. (2021), the 2008 financial crisis increased academic attention to sustainable banking issues. The authors noticed that most of the articles $(88 \%)$ were published between 2009 and 2019. For a long time, the banking industry was considered a non-environmentally sensitive industry that should not be the subject of a more detailed analysis (Chew et al., 2016). Different industries might also have other priorities regarding their engagement in CSR.

Generally speaking, Weber (2014) notes that a bank's impact on the environment can be analysed in four aspects. First, the bank's direct impact is achieved through realized investments in the sectors classified as big polluters because of the control over access to funds. In contrast, indirect impact is achieved through lending activities. Second, the stakeholders of financial institutions can request better environmental practices related to reputational risk. Third, banks started to incorporate shadow prices to respond to environmental risks (such as natural disasters) (Weber, 2014). Last, the financial sector can have a direct and active role as an intermediator (Emtariah et al., 2005). In that aspect, this paper focuses only on the environmental disclosure in the banking sector because: a) it is a highly regulated industry that can enable the economic growth of the country (Nwankwo, 1991), b) many people are directly exposed to the activities of these business institutions, c) banks' lending operations affect social and environmental activities of other industries (Branco and Rodrigues, 2006), d) banks are affected by the state of the natural environment, and d) banks have been considered public trust institutions for a long time (Matuszak et al., 2019), which imposes a responsibility that transcends the boundaries of the business organization itself and is based on an ethical understanding of its responsibility towards the society and the environment (Maon et al., 2009).

To reduce the risk exposure, improve governance and respond adequately to external pressures that can significantly affect environmental disclosure (Brennan and Merkl-Davies, 2014), banks have begun to analyse not only their clients' attitudes towards social and environmental performance but also their cultural journey (Dell'Atti et al., 2020) in terms of whether they have moved from the "banking-as-usual" towards an environmentally and socially sustainable economic development.

The application of disclosure practice varies considerably among countries (Fifka, 2013), primarily in the context of socio-economic and political differences (Orazalin and Mahmood, 2019). In that aspect, environmental disclosure is more 
prevalent in developed countries than in transition or developing ones (Md Zaini et al., 2018). Likewise, the development and implementation of CSR in developing countries are highly influenced by the practice of the MNC or EU companies (Mijatović and Stokić, 2009).

Considering the above assumptions, we were interested in analysing the environmental disclosure practice in the Serbian banking sector for several reasons: a) since the 2000s, it has been undergoing remarkable changes and reforms (Knezevic and Dobromirov, 2016); b) it is the most important generator of Serbia's financial system (National Bank of Serbia, 2019), c) Serbia is a country in transition striving for the EU membership, and in such markets, the socio-economic context is different because the issues of moral, ethical and environmental concerns of financial institutions are vital for them (Matuszak and Różańska, 2017; Evangelinos et al., 2009), and d) in 2020 the Association of Serbian Banks (ASB) joined the IFC-supported Sustainable Banking Network (SBN) making the first step towards sustainable and improved management of environmental, social, and governance (ESG) risks.

In that aspect, this study investigates the environmental disclosure practice of ten banks in Serbia from 2015 to 2019, out of which five are classified as systemically important banks. To assess the environmental disclosure of the sampled banks, annual reports were analysed using content analysis. In conducting the disclosure analysis, the authors constructed an index reflecting important environmental practices in banking. This research will contribute to the literature in several ways. First, it will contribute to the literature on the CSR practice in a transition country by employing the environmental disclosure index (EDI) to explore the extent and the structure of banks' environmental disclosures rather than just focusing on their narrative environment policy. Second, to the best of our knowledge, this is the first study to examine the environmental disclosure practice in the Serbian banking sector based on this methodology, where environmental issues are not considered a part of banks' CSR practice but the main research question. This research will also give an insight into what drives banks' environmental practice activities and reporting about them because banks in transition countries have started to engage in CSR activities only recently (Djalilov et al., 2015). At the same time, the results could raise awareness of the need for CSR reporting among Serbian banks, especially regarding environmental issues.

This paper is organized as follows: the following section gives a literature review on the history of the environmental practice in banking and disclosure practice in Serbia in general. In section 3, research methods, sample, and disclosure process are described. The results are presented in section 4 . The final section concludes the paper and highlights study limitations.

\section{LITERATURE REVIEW}

\subsection{Corporate Social Responsibility Disclosure (CSRD) and environmental practice in banking}

Social norms and the company's responsibility towards the society were subject to examination at the beginning of the $20^{\text {th }}$ century, when business organizations started to develop as legal entities (Krooss, 


\section{Journal of Contemporary Management Issues}

1970). In that aspect, it is important to address certain theoretical bases that have led to such an understanding. This primarily refers to the legitimacy theory. Namely, grounded in the political-economic tradition, the legitimacy theory suggests that the survival of an organization depends on its performance in a socially acceptable way (Panwar et al., 2012). According to Warren (2003), a company is a public institution and cannot be determined only by economic factors but must, in part, include political and social factors because sometimes they can determine the company's fate. Accordingly, legitimacy theory finds that CSR is how organizations confirm or justify the reasons for their survival, profitability, or individual actions and build reputational capital by repaying the debt to society for a successful business (Kundid, 2012). At the same time, legitimacy theory is considered crucial for the company's disclosure practices (Deegan et al., 2002). Issues such as social engagement, relationships with the community, and environmental protection have become just as important as financial indicators (Newberry, 2015), which has led to the development of an approach that some authors call social accounting (Rabun and Williams, 1974), non-financial reporting, or sustainability reporting (Stolowy and Paugam, 2018).

During the 1960s and 1970s (Hart, 1996), the companies did not pay attention to their influence on the environment except for those industries that were directly responsible for the state of the environment in the context of pollution control and energy conservation (Owen and O'Dwyer, 2008). However, an expansion in environmental reporting occurred during the 1990s (Islam et al., 2005) primarily because economic development has consequences for the environment that no one is immune to. In that aspect, it is necessary to create conditions for economic progress that will be economically, socially, and environmentally sustainable (Nieto, 2017; Sućeska and Hanić, 2012). Accordingly, it is necessary for companies to be actively involved in social flows and inform the public about their activities.

In the theory of CSR, reporting on and disclosure of companies' social and environmental activities has led to the development of the Corporate Social Responsibility Disclosure (CSRD) concept. According to Gray et al. (1988), it is a "process of communication between social and environmental effects that a given organization, in economic terms, has on certain stakeholders in society and on society as a whole." Authors like Campbell (2004) or Belal and Lubinin (2009) note that CSRD means disclosing information about the social, ethical, and environmental impacts of a company and its relationship with stakeholders through appropriate communication channels. Weber et al. (2008) and Rosella (2017) point out that the bank's relationship with the environment is conceived through environmental risks as a part of the credit risk management process, especially when it comes to those sectors identified as highly environmentally risky sectors. Nevertheless, environmental issues move from a reputational risk issue to a strategic concern for banks (Bank 2030: Accelerating the transition to a low carbon economy, 2020; KPMG, 2021).

When it comes to research on the disclosure practice in banking, various research questions have been analysed. However, it is important to point out that the degree of disclosure has increased significantly over time (KPMG, 2017), especially regarding banks' climate reporting - in the "front end" (KPMG, 2021). For example, Douglas et al. (2004) analysed annual reports of six banks and four international 
financial institutions in Ireland for the period 1998-2001, including the websites of six banks during 2002. The authors developed a framework for classifying corporate reporting based on four phases: rejection, rhetorical approach, behaviour, and social sensitivity. In the first phase, i.e. rejection, companies believe there is no need to disclose data where the minimum of reporting is achieved within the legal norms. The second phase is characterized by a rhetorical attitude where disclosure is considered necessary to influence the reputation of the company and the management. The third phase, i.e. behaviour, emphasizes an attempt to analyse certain social issues, but only within the company, which means that it is not oriented towards the public. Only in the fourth phase, social sensitivity, does disclosure reach a level in line with society's prevailing norms, values, and expectations. The survey results have showed a complete indifference regarding social issues, emphasizing only the responsibility towards the shareholders.

Branco and Rodrigues (2006) examined the disclosure of social responsibility data of 15 banks in Portugal by analysing their websites during 2004 and then compared them with reports published by banks in previous years. The authors used the content analysis method where the disclosure of data on social responsibility was analysed based on four segments: environment, human resources, products and customers, and community involvement. The results indicate a different degree of data disclosure among banks. For example, all banks in the sample disclosed social responsibility data in their annual reports as opposed to the information found on their websites. Likewise, banks disclosed more information on the environment and human resources in their annual reports compared to the website.
Khan et al. (2009) used a combined approach in the survey. They first analysed annual reports of 20 selected banks in Bangladesh for the period 2004-2005 and then used a questionnaire method to examine the level of understanding of CSR disclosure practice of the 50 report users. The study found that selected banks had a low level of CSR disclosure, highlighting the issue of human resources as the most important in the reports. On the other hand, the report users considered necessary to disclose more data on CSR activities.

Kilic (2015) surveyed a sample of 25 banks in Turkey by analysing their websites. The results showed that nine banks presented social responsibility in a special report while ten banks did it through visual presentation. In other words, banks in Turkey disclosed $48.11 \%$ of data on social responsibility, which leaves room for improvement (Kilic, 2015).

To evaluate the extent of CSR reporting of six large banks from Japan, China, Australia, and India, Jain et al. (2015) used a comprehensive disclosure framework that indicates commitment towards CSR activities in the case of financial institutions. Analysing the period 2005-2011, the authors noted that environmental policy, disclosure of quantitative targets, certified environmental management system, transparency in environmental performance, and risk management in lending policy are categories that measure banks' attitude towards environmental concerns.

On the other hand, Kaium Masud et al. (2017) analysed the context and framework of the environmental accounting and reporting of 20 banks from Bangladesh listed on the Dhaka Stock Exchange. The authors classified 12 major categories important for environmental disclosure. The results indicated that the banks disclosed information 


\section{Journal of Contemporary Management Issues}

for green banking and renewable energy categories, whereas they disclosed the least for environmental recognition and waste management categories. The results also showed that environmental disclosure increased sharply from $16 \%$ in 2010 to $83 \%$ in 2014.

Khan and Tariq (2017) compared the impact of CSR on the financial performance of Islamic and conventional banks in Asia, more specifically Pakistan and Bangladesh, for the period 2010-2015. The variables "Donations", "Social welfare", "Education", "Health", and "Environment" were used as CSR measures to establish how much money the banks had allocated to these types of activities, while ROA, $\mathrm{ROE}, \mathrm{EPS}$, and $\mathrm{P} / \mathrm{E}$ ratio were used as financial measures. The results showed that there is a positive relationship between CSR and financial performance as a result of various social initiatives taken by banks.

Kilic and Kuzey (2019) analysed climate change and its impact on the banking sector. The research included a sample of 24 Turkish banks for the period 2010-2016. The results showed that the number of banks disclosing activities related to climate change had increased. In contrast, a significant number of banks had not yet incorporated this issue into their processes in the context of credit approval policy.

In general, it is evident that disclosure practices vary; a) in the time context of a given research where it increases over time, and $b$ ) with regard to the country or region where the research has been conducted. When it comes to Serbia, that segment is explained below.

\subsection{Disclosure and environmental practice in Serbia}

The issue of the business entities' attitude towards the environment, especially in the field of disclosure practice, is still insufficiently represented either in legal regulations or in Serbian reporting practice. For instance, Stevanović et al. (2016) analysed the environmental reporting practice in Serbia on macro and micro levels. ŠkarićJovanović (2013) focused on the investment aspect of environmental protection while Vićentijević and Petrović (2017) analysed regulations on non-financial reporting in the EU prospect of its introduction and improvement in Serbia. Some authors also researched a selected group of companies (Knežević et al., 2017; Stevanović, 2018; Stevanović et al., 2014).

On a sample of companies included in the Belgrade Stock Exchange index, Belex 15, Knežević and Mijoković (2017) showed that reporting on sustainable development is at a very low level. When reporting on sustainable development, analysed companies focused more on the form of the report than on its content and the given information use-value. Only one company in the sample prepared a special report on sustainable development following the GRI guidelines. Stanisavljević (2017) concluded that nonfinancial performance were not adequately presented in the CSR reports of Serbian companies and that it was necessary to be more harmonized with the EU requirements, which is in line with Pervan et al. (2010) and Pivac et al. (2017). At the same time, Kontić et al. (2012) and Stojanović Aleksić et al. (2016) noted that CSR practice in the Serbian banking sector is closely related to the ownership structure, in terms 
that CSR in Serbia is directly associated with foreign companies' business practices (Vlastelica Bakić et al., 2016).

Stevanović (2018) analysed the environmental reporting practice of a group of companies whose plants are the sources of pollution in the second-largest city in Serbia, Novi Sad, and of companies selected from other local governments in Serbia that had been classified as large polluters. The disclosed information on pollution and environmental protection was released as a special report on environmental protection or was included in the existing annual reports and notes to the financial statements. In a similar research, Stevanović et al. (2014) analysed the environmental disclosing practice of polluting companies in Serbia, focusing on their existing financial statements. Findings showed that most of the disclosed information had resulted from compliance with applicable laws and regulations, while voluntary disclosure was not on an adequate level.

When it comes to the banking sector and the disclosure practice, there have been studies examining the use of this concept among banks in Serbia and its neighbouring countries. For instance, Rogošić (2014) researched social reporting practices among 18 banks in Bosnia and Herzegovina, 31 in Croatia, and 11 in Montenegro. The results showed that only one bank from B\&H had produced a CSR report, three in Croatia and none in Montenegro.

A similar conclusion was reached by Levkov and Palamidovska - Sterjadovska (2019) on a significantly larger sample of 102 banks from the Western Balkan countries. The research was conducted in the period 2015-2017 using the content analysis method. The results showed that out of 102 analysed banks, 47 had not disclosed any form of socially responsible behaviour, while the highest degree of disclosure referred to external issues. In the case of Serbia, the results showed that foreign banks cover both types of disclosure, internal and external, while local banks are focused only on internal disclosure. These results are consistent with Kontić et al. (2012) and Stojanović - Aleksić et al. (2016) arguing that the CSR practice in the Serbian banking sector is closely related to the ownership structure. In other words, CSR in Serbia is directly associated with foreign companies' business practices (Vlastelica Bakić et al., 2016).

The number of studies on environmental reporting practices in the Serbian banking sector is very limited. Knežević et al. (2018) examined waste management reporting practices on a sample of 30 banks for the period 2013-2016. The results indicate that the waste management reporting in Serbian banks is in the early stage but with a growing degree of disclosure from $31 \%$ in 2013 to $46.6 \%$ in 2016 , although still not on an adequate level. This is in line with Stojanović-Aleksić et al. (2016) that the environmental aspect of social responsibility in the Serbian banking sector is in the range from medium to high.

\section{METHODS}

\subsection{Sample and data}

The nature of this research is descriptive and based on secondary data collected through annual or sustainable reports. The use of annual reports is a useful source of data because it usually has a standardized form and provides disclosure of specific data every year and, at the same time, is a publicly available document. Besides, researchers consider it to be an important document where the company has the 


\section{Journal of Contemporary Management Issues}

opportunity to inform the public about the social activities it has undertaken, especially when it comes to topics such as the environment, human rights, and the community.

The process that accompanied the development of environmental disclosure led to a change in the reporting form (Deegan, 2009), where the initially modest information related to social and environmental activities within the annual reports changed into the usage of special publications or the so-called "stand-alone reports" (Owen and O'Dwyer, 2008). Besides, it led to the creation and use of various reporting frameworks such as GRI guidelines, triple bottom line, company's environmental performance information, or sustainability reports (Arnold et al., 2012). This process also enabled the homogeneity of sustainability reports (Bollas-Araya et al., 2014) and the frequent use of sustainability reporting as a basis for environmental issues (Owen and O’Dwyer, 2008).

However, in this process, different disclosure practices are observed in the context of the used report type. Some authors, such as Bouten and Hoozee (2015), note that the application of stand-alone reports is not good because it can be difficult for readers to systemically link information about companies' various policies and practices. Likewise, banks may disclose many documents for that data to be analysed. A different approach involves integrated reporting, which is, according to Kundid Novokmet and Rogošić (2016), "essential for organizations to make more sustainable decisions, and for investors and other stakeholders to understand how well a company is performing".
In this research, a combined approach was applied where integrated annual (or in some cases banks use the term financial) and special (sustainability) reports were studied, considering not only those sections related to the environmental issue but the entire report starting from the mission and vision statement, the CEO report, and other components to gain a complete insight into the bank's attitude towards the environment. The research period refers to 2015-2019. Although 26 banks operate in Serbia, this research included a sample of ten banks, which was determined by the following criteria:

- the bank should have been operating continuously at least one year before 2015 (this refers to the banks whose status changed and as such were not taken into consideration),

- the annual, sustainable or another type of report should have been available for the analysed period, and

- banks that disclosed only financial reports, i.e. a report that includes only the financial data, for the entire analysed period were not considered.

Following the methodology of the National Bank of Serbia (NBS) regarding the bank size, its importance for the economy, the cross-border activities, and the complexity of the bank's operations, five banks from the sample are classified as systemically important. According to NBS, a "systemically important bank is a bank whose deterioration of financial condition or failure would have serious negative effects on financial system stability." This classification is provided by the following table. 
Table 1. Research sample

\begin{tabular}{|l|l|l|}
\hline Bank & Report used & Bank status \\
\hline Banca Intesa & Annual Report + Sustainability Report & Systemically important \\
\hline Unicredit & Annual Report & Systemically important \\
\hline Komercijalna Banka & Annual Report + Communication on Progress Report & Systemically important \\
\hline Raiffeisen Bank & Annual Report & Systemically important \\
\hline Erste Bank & CSR Report & Systemically important \\
\hline Sberbank & Annual Report & \\
\hline Crédit Agricole & Annual Report & \\
\hline Eurobank & Annual Report + CSR Report & \\
\hline NLB Bank & Financial Report + Annual Report & \\
\hline Opportunity Bank & Annual Report & \\
\hline
\end{tabular}

Source: Authors

\subsection{Research methods}

The process of quantifying social responsibility is closely related to the development of CSR. Ehsan et al. (2018) state that although many measures can be used, reputation indices, content analysis, survey research, and analysis of the CSR individual elements are mostly used. The literature review leads to the conclusion that the content analysis method is widespread in research on social topics (Guthrie and Parker, 1990; Kamla, 2007; Parker, 2011).

Abbott and Monsen (1979) define content analysis as "a technique for gathering data that consists of codifying qualitative information in anecdotal and literary form into categories to derive quantitative scales of varying levels of complexity." The application of this method in research on the topic of social performance implies that the scope of reporting on CSR activities is measured based on data available in reports published by companies. In practice, this method works on the counting principle where it is determined whether the requested item is mentioned qualitatively or numerically in the reports. By using it, researchers can systemically process a large amount of data and determine the necessary information. It is a systemic, replicating technique of narrowing many words of text into smaller content categories based on explicit coding rules (Stemler, 2001). According to Guthrie and Abeyseker (2006), this method is usually applied to companies' annual reports.

When it comes to the application of this method in banking, research by authors such as Sapkauskiene and Leitoniene (2014) indicates a wide prevalence of its use. Likewise, in the meta-study conducted by Vourvachis and Woodward (2015), on a sample of 251 analysed studies, it is observed that $60 \%$ involved a disclosure index as a measure of CSR. This approach uses a binary coding system in which a value of 1 indicates that the unit of analysis is present and 0 indicates the opposite. Sapkauskiene and Leitoniene (2014) also point out that a disclosure index should be employed if the aim is to determine the degree and quality of disclosure. In this context, an environmental disclosure index was used in this paper to apply a sentence analysis system, which is consistent with the findings of Milne and Adler (1999). 


\section{Journal of Contemporary Management Issues}

To assess the environmental disclosure practice, Environmental Disclosure Index (EDI) was computed as follows:

$$
E D I_{j t}=\frac{\sum_{i=1}^{n} x_{i j t}}{N}
$$

where the environmental disclosure index, $\mathrm{N}$ is the number of constructs or items disclosed by the bank where $\mathrm{N} \leq 15$, and $\mathrm{Xij}=1$ if construct or item is disclosed, 0 if construct or item is not disclosed, so that $0<=\mathrm{Ij}<=1$.

Since all banks in Serbia still do not use the GRI Guidelines and we focus only on the environmental disclosure issues in this paper, instead of using the GRI Guidelines as a source for creating the disclosure index, we created our composite index. The index consists of 15 variables based on characteristics of the Serbian banking sector as well as on the components used in a research by Jain et al. (2015), Kaium Masud et al. (2017), and Kilic and Kuzey (2019). Although these studies emphasize the importance of environmental disclosure, they focus on certain specifics in the environment - banking sector relation. For example, Kilic and Kuzey (2019) emphasize carbon emission disclosures or climate changes, which is a more specific research context than environmental disclosure issues. On the other hand, Jain et al. (2015) focus on highly developed Asian countries with an international approach in research. Kaium Masud et al. (2017) emphasize their composite index that considers Bangladesh Bank's green policy. In that aspect, the given research was used to consider those variables that could be applied in the banking sector of Serbia.

Table 2. Environmental disclosure index

\begin{tabular}{|l|l|l|l|}
\hline No. & Component & Explanation & Source \\
\hline 1. & Environmental policy & $\begin{array}{l}\text { The bank's attitude towards the } \\
\text { environment: how does the bank treat } \\
\text { this issue in its reports? }\end{array}$ & Jain et al. (2015) \\
\hline 2. & $\begin{array}{l}\text { Water, energy and paper } \\
\text { utilization efficiency }\end{array}$ & $\begin{array}{l}\text { How does the bank deal with the use of } \\
\text { energy, water, and paper recycling? }\end{array}$ & Authors \\
\hline 3. & Waste management and reduction & $\begin{array}{l}\text { Is waste management a part of bank's } \\
\text { internal processes? }\end{array}$ & Authors \\
\hline 4. & $\begin{array}{l}\text { Equipping bank branches using an } \\
\text { eco-friendly approach }\end{array}$ & $\begin{array}{l}\text { Does the bank use environmentally } \\
\text { friendly materials when equipping or } \\
\text { renovating its branches? }\end{array}$ & $\begin{array}{l}\text { Kaium Masud et } \\
\text { al. (2017) }\end{array}$ \\
\hline 5. & $\begin{array}{l}\text { Ecological and carbon } \\
\text { management policy disclosure }\end{array}$ & $\begin{array}{l}\text { What activities has the bank taken to } \\
\text { reduce carbon footprint? }\end{array}$ & $\begin{array}{l}\text { Kaium Masud et } \\
\text { al. (2017) }\end{array}$ \\
\hline 6. & $\begin{array}{l}\text { Cooperation with the local } \\
\text { community to implement } \\
\text { environmental protection projects }\end{array}$ & $\begin{array}{l}\text { Have the bank's employees been } \\
\text { involved in any environmental activities } \\
\text { such as planting trees, cleaning natural } \\
\text { habitats? }\end{array}$ & Authors \\
\hline 7. & $\begin{array}{l}\text { Environmental protection costs - } \\
\text { monetary value }\end{array}$ & $\begin{array}{l}\text { Has the bank disclosed the amount of } \\
\text { funds spent on environmental protection? }\end{array}$ & Authors \\
\hline 8. & $\begin{array}{l}\text { Awards for environmental } \\
\text { protection }\end{array}$ & $\begin{array}{l}\text { Has the bank received awards for its } \\
\text { activities in the field of environmental } \\
\text { protection? }\end{array}$ & Authors \\
\hline
\end{tabular}




\begin{tabular}{|l|l|l|l|}
\hline 9. & $\begin{array}{l}\text { Environmental awareness, training } \\
\text { \& education related disclosure }\end{array}$ & $\begin{array}{l}\text { Does the bank train employees in } \\
\text { environmental issues? }\end{array}$ & $\begin{array}{l}\text { Kaium Masud et } \\
\text { al. (2017) }\end{array}$ \\
\hline 10. & Use of new technologies & $\begin{array}{l}\text { Does the bank use new technologies to } \\
\text { reduce the impact on the environment, } \\
\text { and in what way? }\end{array}$ & Authors \\
\hline 11. & Sponsorship & $\begin{array}{l}\text { Has the bank sponsored any events } \\
\text { aimed at protecting the environment? }\end{array}$ & $\begin{array}{l}\text { Kilic and Kuzey } \\
\text { (2019) }\end{array}$ \\
\hline 12. & Environment certification & $\begin{array}{l}\text { Does the bank have certificates in } \\
\text { environmental protection? }\end{array}$ & Jain et al.(2015) \\
\hline 13. & $\begin{array}{l}\text { Participation in seminars or } \\
\text { conferences that promote } \\
\text { environmental protection }\end{array}$ & $\begin{array}{l}\text { Have the bank's employees participated } \\
\text { in conferences or seminars on } \\
\text { environmental protection? }\end{array}$ & $\begin{array}{l}\text { Kilic and Kuzey } \\
\text { (2019) }\end{array}$ \\
\hline 14. & $\begin{array}{l}\text { GHG emissions and energy } \\
\text { consumption accounting }\end{array}$ & $\begin{array}{l}\text { Does the bank disclose the level of GHG } \\
\text { emissions and energy consumption? }\end{array}$ & $\begin{array}{l}\text { Kilic and Kuzey } \\
\text { (2019) }\end{array}$ \\
\hline 15. & $\begin{array}{l}\text { Placement of socio-ecological } \\
\text { products }\end{array}$ & $\begin{array}{l}\text { Has the bank created any products that } \\
\text { consider the socio-environmental effects } \\
\text { of the investment? }\end{array}$ & Authors \\
\hline
\end{tabular}

In order to apply the method of content analysis appropriately, it is necessary to define precise rules when calculating the index, which refers to the following:

- The emphasis is placed on disclosure practice aimed at getting the analysed banks well acquainted with this practice, which means that the analysed items received a value of 1 only in the case of a detailed disclosure.

- This study did not consider the annual or sustainability reports of parent banks because the research aim is to determine the degree of environmental disclosure applied by the banks in Serbia, both domestic and foreign (subsidiary). In that aspect, sustainability reports by Raiffeisen Group were not considered even though Raiffeisen Bank based in Serbia was a part of the Group reporting but to a very limited extent. The same practice was applied in case of Banca Intesa because only the sustainability reports of the Intesa Group were published for 2018 and 2019 on their website.

In addition to EDI, we also created an econometric model where the observation units were the banks in Serbia that met the predefined criteria for analysis entered the research sample. The EDI variable was selected as a dependent variable, while the independent variables were the bank status, return on activity (ROA), and return on equity (ROE). The general form of the model used to evaluate the panel data is presented below (Baltagi, 2005):

$$
y_{i t}=\alpha+X_{i t}{ }^{\prime} \beta+u_{i t}, \mathrm{i}=1, \ldots, \mathrm{N} ; \mathrm{t}=1, \ldots, \mathrm{T} .
$$

In the general form of the model, $i$ denotes the units of observation, $t$ represents time periods, $\alpha$ is a scalar, $\beta$ is $\mathrm{K}^{\mathrm{x} 1}$, and $X_{i t}$ is an observation of the $\mathrm{K}$ explanatory variables. In this research, $i$ represents banks, $t$ is the annual time periods, while the explanatory variables are the status and financial performance of banks. When testing the hypotheses and after calculating the appropriate tests of specification (to be 


\section{Journal of Contemporary Management Issues}

discussed in later segments of the paper), the model of random effects was selected as the most appropriate one. The general form of this model can be written in the form:

$$
y_{i t}=\alpha+X_{i t}{ }^{\prime} \beta+\left(\mu_{i}+\lambda_{t}+v_{i t}\right), \mathrm{i}=1, \ldots, \mathrm{N} ; \mathrm{t}=1, \ldots, \mathrm{T}
$$

In this equation, $\mu_{i}$ denotes unnoticed individual effects, $\lambda_{t}$ denotes the effects of time variables, while $v_{i t}$ represents the residue of a random error. An additional argument in favour of using a random effects model is that it is more suitable for estimating a smaller number of parameters. In addition to this advantage, the random effects model allows inclusion of the variables that have constant values over time (i.e., artificial variables).

\subsection{Results}

Regarding the environmental disclosure practice, analysed banks treat this issue differently in their reports. Some banks give it a special attention by positioning it in the CEO message. On the other hand, others put it in a special section of the report devoted to the issue of the environment or in the part related to the CSR practice. EDI values are presented in Figure 1.

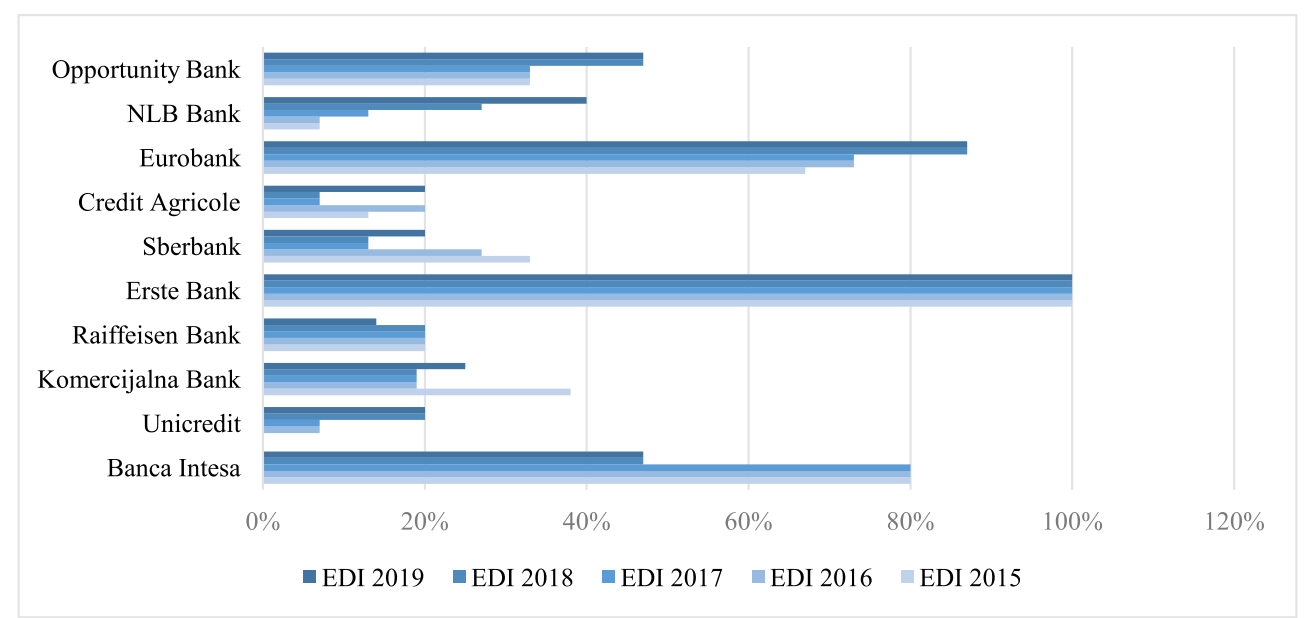

Figure 1. EDI values in the period 2015-2019

Source: Authors.

As seen from the chart, environmental disclosure practice is rising, which is a positive trend in the Serbian banking sector. At the same time, however, the reporting practice is inconsistent, which means that all the data are not disclosed in all the observed years. In other words, the reports are not standardized. Regarding the disclosure of the EDI components, the most disclosed ones refer to environmental policy (74\%), cooperation with the local community in the implementation of the environmental protection projects $(51 \%)$, and water, energy, and paper utilization efficiency (48\%), as presented by Figure 2 . 




Figure 2. Most disclosed EDI variables

Source: Authors.

Regarding the banks ranking, the results

present in just one systemically important indicate that disclosure practice is fully

bank in Serbia, as presented by Table 3.

Table 3. Banks' ranking according to the average EDI value

\begin{tabular}{|c|c|c|}
\hline Bank & EDI Score & EDI Score Ranking \\
\hline Unicredit & $0.108(10.8 \%)$ & 10 \\
\hline Crédit Agricole & $0.134(13.4 \%)$ & 8 \\
\hline NLB Bank & $0.188(18 \%)$ & 7 \\
\hline Raiffeisen Bank & $0.188(18.8 \%)$ & 6 \\
\hline Sberbank & $0.212(21.2 \%)$ & 5 \\
\hline Komercijalna Banka & $0.24(24 \%)$ & 4 \\
\hline Opportunity Bank & $0.386(38.6 \%)$ & 3 \\
\hline Banca Intesa & $0.668(66.8 \%)$ & 2 \\
\hline Eurobank & $0.774(77.4 \%)$ & 1 \\
\hline Erste Bank & $1.0(100 \%)$ & 8 \\
\hline
\end{tabular}

Source: Authors.

Erste Bank is ranked as number one. In the case of non-financial reporting, this bank follows the GRI methodology, and since 2008, the bank has been publishing annual reports on social responsibility that were used in this analysis. In practice, the bank addresses the issue of climate change and financing as follows: "Recognizing climate change as one of the greatest global challenges of today's society, Erste Bank is committed to financing various energy efficiency and renewable energy projects" (Erste Corporate Social Responsibility Report, 2019). Erste Bank also discloses the amount of money invested in the environmental projects during the analysed period, 


\section{Journal of Contemporary Management Issues}

unlike other banks in the sample that most often disclose the total amounts placed in social responsibility projects, including the environment.

A high degree of disclosure is present in the case of Eurobank, ranked as second in the EDI value. Compared with Erste Bank, a difference in disclosure practice is minor because all relevant environmental data are disclosed in this bank's reports. The difference is more technical in the sense that certain elements such as the amount of money spent on environmental protection or participation in gatherings or conferences that promote environmental issues are not disclosed in certain years. In the case of this bank, it is also noticed that the degree of disclosure increases over time, being the highest in the last two years.

Regarding Banca Intesa, for 2017 and 2018 , the level of disclosure is lower because the sustainability report was available only at the Group level, which was not considered. This bank addresses the environmental issues not only in a special part of the report, i.e. the so-called Environment section, but also in the CEO message, which emphasizes the bank's commitment to sustainable development minimizing the bank's negative impact on the environment. Since 2105, the bank has been implementing GRI G4 reporting guidelines for the Serbian market.

Despite being a non-systemic bank in the Serbian banking sector, Opportunity Bank has a satisfactory disclosure rate compared to much larger banks such as Komercijalna Banka or UniCredit. For instance, although the environmental disclosure level of UniCredit bank has increased over time, it is still insufficient. One of the factors that influenced the EDI value of this bank was the fact that the bank did not disclose its sustainability report. Instead, the sustainability issue was disclosed in the report at the Group level, which was not taken into consideration. The same situation is present in the case of Raiffeisen Bank.

Regarding Komercijalna Banka, the bank's United Nations Global Compact reports were also used in the analysis. However, the reports are not standardized as the degree of disclosure varies during the analysed period. Thus, for example, the issue of water, energy, and paper utilization efficiency was not mentioned in all the analysed years.

Although Sberbank emphasizes the environmental protection policy in all its reports, including the types of cooperation with the local community in the implementation of environmental protection projects, the degree of disclosure is inconsistent. This is particularly present in branch equipping applying an eco-friendly approach or water, energy, and paper utilization efficiency. The bank did not disclose whether it had participated in meetings or conferences that promoted environmental protection, environment certification, and placement of socio-environmental products.

The last two banks, Crédit Agricole and UniCredit, have a disclosure rate of less than $15 \%$. In the case of Crédit Agricole, the bank did not disclose its commitment to reduce the negative impact on the environment. The topics such as environmental awareness, training and education or water, energy, and paper utilization efficiency were also not disclosed.

Finally, the results can be summarised as follows:

- Although Serbian banks have recently started to take part in environmental activities, most of the sampled banks have an environmental policy 
emphasizing their commitment to reducing the negative impact on the environment. That commitment is emphasized in the CEO message. It is closely related to the practice of implementing socio-environmental risk analysis of their clients. At the same time, the banks are very active in their cooperation with the local community, aiming to implement environmental protection projects such as participation of employees in river cleaning, reforestation, equipping schools, etc. Most of these activities are followed by the values that parent banks in the western countries impose, so those same values drive subsidiaries in Serbia;

- The issue of attitudes towards efficient use of energy, water, paper recycling has an upward trend, while in the case of waste management, it is in the medium range, as confirmed by Knežević et al. (2018). Banks have also begun to actively apply new technological solutions for electricity consumption and an eco-friendly approach when equipping bank branches;

- Banks that follow the GRI methodology also disclose GHG emissions and the general issue of climate change, which is emphasized in a smaller percentage;

- Some banks organize environmental awareness and education training for their employees as well as participation in meetings or conferences that promote the environmental issue;

- Most banks disclose the total amount spent on CSR activities, including the environmental issue, while the amount of funds spent only on environmental protection activities is disclosed less. This is the least disclosed item within EDI.
- Although all banks sponsor many social activities, there is a smaller number of banks oriented to sponsoring exclusively environmental events, or the banks have not disclosed it.

- The degree of disclosure in most banks is inconsistent, leading to the conclusion that the reports are not standardized.

After calculating EDI, we wanted to explore whether the degree of disclosure is higher in the case of systemically important banks from the sample or not. Since we had five systemically and five non-systemically banks, we also wanted to explore if there was a positive relationship between Serbian banks' EDI index and their financial performance. Generally, the examination of the link between CSR and financial performance dates back to 1972 when first papers (Bragdon and Marlin, 1972; Moskowitz, 1972) were published, which had the character of an "antidote" for a public that was sceptical regarding CSR.

When analysing the literature dealing with the topic of CSR and financial performance, most of the authors have addressed the following issues:

1. Is there a link between CSR and financial performance at all?

2. Is the relationship between these two components examined in the short run, when the company has an unexpectedly large return after engaging in social activities, or in the long run, using accounting or financial profitability indicators (Hirigoyen and Poulain-Rehm, 2015)?

3. What is the direction of the relationship, and what is the type of relationship? In terms of the direction of the relationship or, as some authors cite, 


\section{Journal of Contemporary Management Issues}

causal relationships, it may go in the direction that social performance affects financial performance or that financial performance affects the social one or that there is a certain degree of synergy between the two analysed concepts, while, when it comes to the type of relationship, it can be positive, negative, or neutral (Preston and O'Bannon, 1997);

4. Do the measures used to establish the link between CSR and financial performance affect the final result (Griffin and Mahon, 1997)?

For instance, Margolis and Walsh (2003) analysed 127 studies published between 1972 and 2002 and concluded that:

- 54 studies showed a positive link between CSR and financial performance,

- 28 studies showed that there was no link between CSR and financial performance,

- 7 studies showed a negative link between CSR and financial performance, and

- 20 studies showed mixed results.

Simpson and Kohers (2002) argue that financial parameters of ROA and ROE are the most representative indicators of the banks' financial performance, and as such, are most often used in the analysis of the banking sector. These parameters have been used as inputs in statistical models to predict bank failures, mergers, and many other purposes that require profitability measurement (Gilbert and Wheelock, 2007). In that aspect, we tested the following hypotheses:

H1: Bank status has a positive impact on the movement of EDI values.

Systemically important banks are those called "too big to fail." In that aspect, they can be classified as big banks. In a CSR context, the size of a company affects the company's ability to undertake social activities. Likewise, as a company grows, it becomes more present in social issues and the responsibility towards stakeholders increases. In the banking sector, Goddard et al. (2004) note that bank size could be one of the bank profitability determinants. On the other hand, Dietrich and Wanzenried (2011) point out that large banks have greater product diversification compared to smaller banks, thus achieving economies of scale. In the context of CSR and data disclosure, Fry and Hock (1976) believe that size-related variables are most important when researching quantity disclosure of data on social activities. Authors like Kilic et al. (2015) or Coluccia et al. (2016) note that, in general, company size has a positive effect on CSR disclosure practice.

When analysing the size and its relationship with CSR disclosures, it is closely related to the previously mentioned legitimacy theory. According to Deegan and Unerman (2011), legitimacy theory highlights that organizations constantly strive to ensure that companies are treated as those operating within the boundaries and norms of the society in which they operate. In that aspect, besides financial indicators, the public has become interested in a segment related to non-financial data about the company's activities and its responsibility towards the society, and it is expected that big companies, in this case, systemically important banks, will have a higher degree of disclosure.

H2: There is a positive relationship between Serbian banks' EDI index and their financial performance, measured by ROA.

Wang and Wang (2015) define ROA as a variable that shows how efficiently the bank management uses assets to generate profit. 
Reger et al. (1992) state that this parameter is the most important financial indicator in the banking industry. Orlitzky et al. (2003) conducted a meta-analysis on a sample of 52 studies for the period 1970-2002 with a total of 33,878 observations. The study concludes there is a "positive link between social performance and financial performance in different industries and study contexts." In another research, Mallin et al. (2014) analysed the relationship between the CSR disclosure index and financial performance of 90 Islamic banks from 13 countries in the period 2010-2011. The results indicate that there is a positive and significant relationship between the CSR and financial performance, but the direction of influence is moving from financial performance towards the CSR.
H3: There is a positive relationship between Serbian banks' EDI index and their financial performance, measured by ROE.

ROE can be used to determine past performance in terms of determining future movements (Wilcox, 1984). Hopkins et al. (1997) consider ROE as the ultimate measure of strength of any financial institution. According to Wang and Wang (2015), ROE represents a variable that tells how competent the bank's management is to generate returns for stockholders.

It is important to emphasize that the parameters ROA and ROE were not observed together in this paper because of a high correlation between them. The following table shows the basic descriptive statistics of the sample.

Table 4. Descriptive statistics

\begin{tabular}{|c|c|c|c|c|c|c|}
\hline Variable & & Mean & Std. Dev. & Min. & Max & $\mathbf{N}$ \\
\hline \multirow[t]{3}{*}{ ROA } & overall & \multirow[t]{3}{*}{1.476} & 0.767 & -0.47 & 2.64 & 50 \\
\hline & between & & 0.727 & 0.378 & 2.462 & 10 \\
\hline & within & & 0.32 & 0.382 & 2.282 & 5 \\
\hline \multirow[t]{3}{*}{ ROE } & overall & \multirow[t]{3}{*}{8.201} & 4.157 & -2.15 & 14.55 & 50 \\
\hline & between & & 3.883 & 1.914 & 13.064 & 10 \\
\hline & within & & 1.853 & 4.137 & 12.651 & 5 \\
\hline \multirow[t]{3}{*}{ EDI } & overall & \multirow[t]{3}{*}{39.07} & 31.247 & 0.0 & 100 & 50 \\
\hline & between & & 31.205 & 10.68 & 100 & 10 \\
\hline & within & & 9.059 & 19.27 & 61.73 & 5 \\
\hline
\end{tabular}

Source: Authors

If we divide the sample into one that is consistent with systemically important and the other one consistent with non-systemically important banks, the average values of the ROA coefficient do not record significant differences. In other words, the returns on the total engaged assets of systemically and non-systemically important banks are of similar values $(1,868$ and 1,084 , respectively). It is important to note that all ROA values regarding systemically important banks are positive. In contrast, in nonsystemically important banks, one case of negative ROA value was recorded. Hence, the average value of the coefficient in this group of banks is slightly lower compared to the other group. Namely, the ROA ratio in systemically important banks ranged from 1.01 to 2.5 and in non-systemically important banks from -0.47 to 2.64. A 


\section{Journal of Contemporary Management Issues}

significant difference can be noticed in the average value of the ROE coefficient, so the return on equity for systemically important banks is 10,630 , while it is 5,771 for nonsystemically important banks.

Differences in the average values of the ROE coefficient can be explained as in the case of the ROA coefficient. First of all, among the realized values of the ROE coefficient at non-systemically important banks, one negative value is recorded $(-2.15)$, while the maximum realized value is 14.08 . On the other hand, systemically important banks recorded only positive values of the ROE ratio. Its minimum value in the observed period was 7.43 and the maximum 14.55. The values of the EDI index also differ according to the bank's status. The systemically important banks record higher index values compared to non-systemically important ones $(44,576$ and 33,564 , respectively).

An econometric analysis of panel data, i.e. the panel method, was used to assess the effects of the bank's status on EDI value. The panel database used in this paper consists of data in which a dependent variable EDI and the independent variables ROA and ROE vary in two dimensions: time $(\mathrm{t})$ and individual (s). We introduced the artificial variable, bank status, which takes the value 1 if the bank is marked as systemically important, and the value 0 if the bank is marked as non-systemically important.

Dragutinović-Mitrović (2002) note that the panel series contains data from many of the same observation units at certain time points. In this case, the observation units are systemically and non- systemically important banks in Serbia, whose financial performance and EDI vary in several consecutive time periods $(T=5)$. If there is a large number of observations and a small number of time periods, two groups of econometric panel models can be used: the so-called models with constant regression parameters and the so-called models of individual effects (Cameron and Trivedi, 2010). In this paper, the analysis is directed towards the models of individual effects.

In the literature on models of individual effects, two models are distinguished (Cameron and Trivedi, 2010): a fixed effects model and a random effects model. According to Dragutinović-Mitrović (2002), to use the fixed effects model, the independent variable must vary both among banks and in time, while it is necessary to fulfil an assumption of no correlation between random effects and regressors to apply the random effects model. If both assumptions are met, the estimates of both models are considered unbiased and consistent. However, estimates of random effects models have the least variance, so they are considered effective (Cameron and Trivedi, 2010).

In accordance with the methodological explanation, we will first present the test results within the examination of whether there is a positive impact of the bank's status on EDI value. In other words, the obtained results should either reject or accept the first (and basic) hypothesis of this paper. The Hausman specification test was calculated to choose between the fixed effects model and the random effects model. Based on the test value, justification of using the random effects model in assessing the effects of the bank's status on the EDI index value is confirmed. Following the decision, the table below shows the results of the analysis. 
Table 5. Random effects model results (Model 1)

\begin{tabular}{|l|l|}
\hline & Random Effects Model (1) \\
\hline Variables & Coefficient \\
\hline Status & 11.012 \\
\hline Constant & $33.564^{* * *}$ \\
\hline
\end{tabular}

Note: ${ }^{* * *} \mathrm{p}<0.01,{ }^{* *} \mathrm{p}<0.05,{ }^{*} \mathrm{p}<0.1$

Source: Authors.

The results indicate that the parameter next to the bank status independent variable is not statistically significant and that this variable has no effect on the selected banks' EDI. In other words, one of the important characteristics of the (systemically important) banks does not affect the EDI independent variable. The overall R2 value for this model is 0.0317 , so it can be concluded that approximately "only" $3.2 \%$ of the variance in the rate of change in the EDI index value can be explained through variations of the bank status independent variable. However, the low value of the coefficient of determination indicates that the model needs to be expanded with new variables to explain the higher percentage of variations in the EDI values by variations of independent variables. Based on the obtained results and with a significance level of $95 \%$, there is not enough evidence to accept the tested hypothesis, so it can be concluded that the bank status does not affect the EDI values of selected banks. In other words, systemically important banks in Serbia do not have a higher degree of environmental disclosure. This is consistent with Kundid (2012) who stated that big, i.e. systemically important, banks in transition countries have a weaker disclosure practice than their parent banks. At the same time, three of the observed banks disclosed only the sustainability reports of the Group, which affected the EDI value of the sample.

The analysis was expanded by testing two independent variables that indicate the banks' financial performance, which is widely used in the literature (Simpson and Kohers, 2002; Jewell and Mankin, 2011; Mallin et al., 2014). The results of models 2 and 3 are presented in the following table.

Table 6. Results of the random effects model (Model $2 \& 3$ )

\begin{tabular}{|l|c|c|c|}
\hline Variables & \multicolumn{2}{|c|}{ Model 2 } & Model 3 \\
\hline ROA & $-7.493^{* *}$ & $(3.081)$ &. \\
\hline ROE &. & $()$. & -1.170 \\
\hline Constant & $50.127^{* * *}$ & $(12.477)$ & $48.665^{* * *}$ \\
\hline Observation & \multicolumn{2}{|c|}{50} & 50 \\
\hline Number of ID & 10 & 10 \\
\hline Hausman test & 0.4174 & 0.4556 \\
\hline
\end{tabular}

Note. Standard errors in parentheses. ${ }^{* * *} \mathrm{p}<0.01,{ }^{* *} \mathrm{p}<0.05,{ }^{*} \mathrm{p}<0.1$

Source: Authors. 


\section{Journal of Contemporary Management Issues}

Financial performance indicators were gradually introduced into the analysis. First, a model was tested by including an independent ROA variable (Model 2). By including the explanatory variable ROA in the model, the influence of one of the internal determinants of profitability was tested. Estimation results indicate that ROA has a statistically significant effect on EDI. However, the coefficient that stands next to the explanatory variable has a negative sign, which indicates an inverse relationship between ROA and EDI. In other words, the higher values of the financial ROA indicator correspond to lower values of the EDI variable.

The initial hypothesis was created on the basis of previous research and literature reviews. However, using available data that have satisfied a reasonable level of reliability, it can be said that the internal determinant of ROA bank profitability does not positively affect the height of the EDI index. In other words, hypothesis 2 was rejected and we concluded that we did not have enough evidence to accept the claim that higher values of the financial ROA indicator correspond to higher values of the EDI variable.

Due to the problem of multicollinearity, financial indicators were included individually in the econometric analysis of panel data, and odel 3 represents an estimation of the effects and direction of the impact of the financial indicator ROE on the height of the EDI variable. The Hausman specification test showed the selection of a random effect model compared to a fixed effect model. Based on the obtained results, it is noticed that the value of the coefficient with the explanatory variable ROE is positive, but it is not statistically significant. In other words, the internal determinant of ROE bank profitability does not affect the movement of the
EDI variable value, although the expected sign of the coefficient is positive. According to the obtained results, the initial research hypothesis 3 was rejected and we concluded that we do not have enough evidence to be able to claim with certainty that higher values of the ROE coefficient correspond to higher values of the EDI variable.

The obtained results are in line with Matuszak and Różańska (2017) in the context that banks CSR activities are not a dominant predictor of their profitability, which means that financial performance does not correspond to CSR activities. A similar conclusion was reached by Amirul et al. (2017), who assessed the impact of CSR categories on the ROE of a bank in Malaysia for the period 2011-2015. The results showed that financial performance does not correspond to CSR activities, since in the years when ROE is falling, banks' corporate social responsibility activities are growing and vice versa. If we take into account that Serbia is not a developed country, these results are in line with Aras et al. (2010) who did not find any significant links between the CSR and financial performance on the example of business entities from developing countries. Chih et al. (2010) also empirically investigated a total of 520 financial firms in 34 countries in the period 2003-2005 and concluded that CSR and financial performance were not related.

In theoretical terms, the obtained results can be observed through the prism, which was previously presented by Preston and O'Bannon (1997), of the existence of the so-called trade-off hypothesis, which means that greater engagement of the company in the field of CSR means lower financial performance, i.e. where a higher (lower) level of social performance leads to a lower (higher) level of financial performance. Since the financial performance of ROA 
and ROE could not be included together in estimating the effects of financial indicators on the value of the EDI index, the following table shows a matrix of correlation coefficients between the observed variables.

Table 7. Correlation matrix between EDI (dependent variable), ROA, and ROE (independent variables)

\begin{tabular}{|l|c|c|c|}
\hline & EDI & ROA & ROE \\
\hline EDI & 1 & & \\
\hline ROA & 0.0588 & 1 & 1 \\
\hline ROE & 0.0687 & $0.8859^{* * *}$ & \\
\hline
\end{tabular}

Note. ${ }^{* * *} \mathrm{p}<0.01,{ }^{* *} \mathrm{p}<0.05,{ }_{\mathrm{p}<0.1}^{*}$

Source: Authors

In the correlation matrix given in Table 7 , it is noticeable that there is a positive correlation between all the variables and that the growth of one variable is accompanied by the growth of another variable. However, based on the p-value, it is concluded that only the correlation coefficient between the variables ROA and ROE is statistically significant, while the other correlation coefficients are not. Namely, there is an extremely high correlation between the variables ROA and ROE, given the coefficient of 0.89 . As the coefficient is both positive and statistically significant, it is clear that including both variables simultaneously could undermine the assumption of multicollinearity. Since, according to Mladenović and Petrović (2007), multicollinearity occurs in models with high correlation, a joint observation of financial performance will be omitted from the analysis. Based on the correlation coefficient, only the degree of dependence can be determined, but not the causality. In other words, it does not show whether an increase in the value of the EDI index causes an increase in the value of the ROA or vice versa. Therefore, the basis of this paper is the econometric analysis of panel data, which, using available data with a reasonable level of reliability, showed that the bank status does not affect the EDI variable value, but also raised new research questions on the impact of financial performance on EDI index values.

The results presented in this paper, within the econometric analysis of panel data, point to the conclusion by which hypotheses 2 and 3 are rejected. In other words, the positive relationship between financial performance (ROA and ROE) and EDI is not confirmed on the selected sample of banks in Serbia. Further research is necessary to estimate the effects of other control variables on the EDI index values.

\section{CONCLUSION}

Environmental disclosure practice has become a widespread activity present in all industries, including banking. However, unlike the developed countries, disclosure practice in transition and developing countries is not still at an adequate level, especially in the context of socio-economic and political differences (Orazalin and Mahmood, 2019). Based on this, we were interested in analysing the environmental disclosure practice in the Serbian banking sector. As a country in transition, gaps in social welfare and corporate governance are greater (Fifka, 2013). It is also the most important generator of Serbia's financial 


\section{Journal of Contemporary Management Issues}

system, and this research gives an insight into the disclosure practice among the financial generators of a country.

The aim of this paper was to analyse the environmental disclosure practice in the Serbian banking sector and determine whether the degree of disclosure is higher in the case of big, i.e. systemically important, banks to examine if there is a positive relationship between the banks' CSR practice and their financial performance. As a measure of environmental performance for the Serbian banking industry, the environmental disclosure index (EDI) was employed, consisting of 15 variables based on the characteristics of the Serbian banking sector as well as on the components used in research by Jain et al. (2015), Kaium Masud et al. (2017), and Kilic and Kuzey (2019).

The data were generated through content analysis of the annual, sustainability, or other types of reports, excluding reports that disclose only the financial data, of a total of 10 banks five out of which were classified as systemically important for the period 2015-2019. Regarding the disclosure practice, the results show that most of the sampled banks have an environmental policy emphasizing their commitment to reducing the negative impact on the environment and are very active in cooperation with the local community in the implementation of the environmental protection projects.

At the same time, Serbian banks disclose both qualitative and quantitative information in different sections of the annual reports. In that aspect, one of the findings in this research is that in transition countries, the use of integrated reporting is important. Although the environmental disclosure practice among banks in Serbia is growing, the problem of inconsistency is present because not all data are disclosed every year, which leads to the conclusion that the development and implementation of CSR in developing countries usually begin when MNCs open branches in those countries. In other words, it could be said that the same values drive Serbian banks as their parent banks in developed countries.

To assess the effects of the banks' status on EDI value, an econometric analysis of panel data, i.e. the panel method, was used where EDI was the dependent variable while ROA and ROE had a status of independent variables. We introduced the artificial variable, bank status, which takes the value 1 if the bank is marked as systemically important and the value 0 if the bank is marked as non-systemically important. The results show that systemically important banks in Serbia do not have a higher degree of environmental disclosure compared to non-systemically important banks. This is consistent with Kundid (2012) in terms that big banks (systemically important banks) in transition countries have a weaker disclosure practice than their parent banks. At the same time, three of the observed banks disclosed only the sustainability reports of the Group, which affected the EDI value of the sample.

Regarding the examination of the relationship between Serbian banks' EDI index and their financial performance, we rejected the hypothesis that there was a positive relationship between Serbian banks' EDI index and their financial performance measured by ROA. The value of the estimated coefficient in model $2(-7.493)$ suggests that we do not have enough evidence to accept the claim that higher values of the financial ROA indicator correspond to higher values of the EDI variable. In the case of ROE, the estimated coefficient value in model $3(-1.107)$ is negative, but not statistically significant. In other words, the internal 
determinant of ROE bank profitability does not affect the movement of the EDI variable value, so it is concluded that there is no positive relationship between the Serbian banks' EDI index and their financial performance measured by ROE.

Environmental issues, including transparency and accountability, deserve a special research focus, especially in countries like Serbia, where disclosure practice differs from the ones in developed countries. In that aspect, this paper contributes to the environmental disclosure practice in Serbia, mainly for CSR, because this research considers the environment as a stakeholder. This study also has implications for policymakers and accounting bodies in Serbia in terms of standardizing the non-financial reporting and creating certain green and sustainable banking guidelines. We believe this is important because Serbia has a very stable banking sector and if transparent and socially responsible financial policies are applied, it can stimulate the preservation of ecosystems and enable a better implementation of sustainable development goals at the entire country level.

This research also has its limitations that may affect the reliability of the results. First, many banks in Serbia have undergone the process of transformation, which has affected the sample structure and the availability of the reports for the analysed period. Since the data were very limited, we tried to adapt the methodology according to the literature review and in line with available data. To the best of our knowledge, this is the first study in Serbia about environmental disclosure practices among systemically and non-systemically important banks and their relationship with financial performance.

\section{REFERENCES}

1. Abbott, W. F., Monsen, R.J. (1979). On the measurement of corporate social responsibility: Self-reported disclosures as a method of measuring corporate social involvement. Academy of Management Journal, 22, 501-515.

2. Abdul Rashid, N.R.N., Annuar Khlaid, S., Abdul Rahman, N.I. (2015). Environmental Corporate Social Responsibility (ECSR): Exploring its Influence on Customer Loyalty. Procedia Economics and Finance, 31, $705-713$.

3. Amirul, A.M., Jaafar, M.N., Basri, M.F. (2017). Corporate Social Performance (CSP) Influences on Islamic Bank's Financial Performance. Journal of International Business, Economics and Entrepreneurship, 2(1), 11-16.

4. Aracil, E., Nájera-Sánchez, J-J., Forcadell, F.J. (2021). Sustainable banking: A literature review and integrative framework. Finance Research Letters, 1-10.

5. Aras, G., Aybars, A., Kutlu, O. (2010). Managing corporate performance: Investigating the relationship between corporate social responsibility and financial performance in emerging markets. International Journal of Productivity and Performance Management, 59(3), 229-254.

6. Arnold, M. C., Bassen, A., Frank, R. (2012). Integrating sustainability reports into financial statements: An experimental study. SSRN Electronic Journal. Retrieved from https://papers.ssrn.com/sol3/papers. cfm?abstract_id=2030891.

7. Baltagi, B.H. (2005). Econometric Analysis of Panel Data. John Wiley \& Sons Ltd. 


\section{Journal of Contemporary Management Issues}

8. Banking Environment Initiative. (2020). Bank 2030: Accelerating the transition to a low carbon economy. University of Cambridge Institute for Sustainability Leadership.

9. Bansal, P., \& Roth, K. (2000). Why Companies Go Green: A Model of Ecological Responsiveness. The Academy of Management Journal, 43(4), 717-736.

10. Baughn, C., Bodie, N., McIntosh, J., (2007). Corporate social and environmental responsibility in Asian countries and other geographical regions. Corporate Social Responsibility and Environmental Management, 14(4), 189-205.

11. Belal, A.R., Lubinin, V. (2009). Russia: Corporate social responsibility. Global Practices of Social Responsibility, 1, 165-179.

12. Bollas-Araya, H-M., Seguí-Mas, E., Polo-Garridio, F. (2014). Sustainability reporting in European cooperative banks: An exploratory analysis. REVESCO. Revista de Estudios Cooperativos, 1-27.

13. Bouten L., Hoozee S., (2015). Challenges in Sustainability and Integrated Reporting, Issues in Accounting Education, 30(4), 373-381.

14. Bragdon, J. H., Jr., Marlin, J.A.T. (1972). Is pollution profitable? Risk Management, 19(4), 9-18.

15. Branco, M.C., Rodrigues, L.L. (2006). Communication of corporate social responsibility by Portuguese banks: A legitimacy theory perspective. Corporate Communications: An International Journal, 11(3), 232-248.

16. Brennan, N. M., Merkl-Davies, D. M. (2014). Rhetoric and Argument in Social and Environmental Reporting: The Dirty Laundry Case. Accounting,
Auditing and Accountability, 27(4), 602-633.

17. Cameron, A.C., Triverdi, P.K. (2009). Microeconometrics Using Stata. Stata Press.

18. Campbell, D. (2004). A longitudinal and cross-sectional analysis of environmental disclosure in UK companies - a research note. The British Accounting Review, 36(1), 107-117.

19. Chew, B.C., Tan, L.H., Hamid, S.R. (2016). Ethical banking in practice: a closer look at the Co-operative Bank UK PLC. Qualitative Research in Financial Markets, 8(1), 70-91.

20. Chih, H-L., Chih, H-H., Chen, T-Y. (2010). On the Determinants of Corporate Social Responsibility. International Evidence on the Financial Industry. Journal of Business Ethics, 93(1), 115-135.

21. Coluccia, D., Fontana, S., Solimene, S., and D'Amico, E. (2016). Factors Influencing Corporate Environmental Disclosure. Business Strategy and the Environment, 25(3), 178-192.

22. Deegan, C. (2009). Financial accounting theory. McGraw Hill Australia Pty Ltd.

23. Deegan, C., Rankin, M., Tobin, J. (2002). An examination of the corporate social and environmental disclosures of BHP from 1983-1997: A test of legitimacy theory. Accounting, Auditing \& Accountability Journal, 15(3), 312-343.

24. Deegan, C., Unerman, J. (2011). Financial Accounting Theory. McGraw-Hill Higher Education, New York.

25. Dell'Atti, S., Donofrio, F., Onorato, G. (2020). A State of the Art of Corporate Social Responsibility in Financial Institutions. Avaliable at: https://www. 
Management, Vol. 26, 2021, No. 2, pp. 115-144

A. Hanić, O. Jovanović, S. Stevanović: ENVIRONMENTAL DISCLOSURE PRACTICE ...

intechopen.com/online-first/a-state-ofthe-art-of-corporate-social-responsibility-in-financial-institutions

26. Dietrich, A., Wanzenried, G. (2011). Determinants of bank profitability before and during the crisis: Evidence from Switzerland. Journal of International Financial Markets, Institutions and Money, 21(3), 307-327.

27. Djalilov, K., Vasylieva, T., Lyeonov, S., Lasukova, A. (2015). Corporate social responsibility and bank performance in transition countries. Corporate Ownership \& Control, 13(1), 879-888.

28. Douglas, A., Doris, J., Johnson, B. (2004). Corporate social reporting in Irish financial institutions. The TQM Magazine, 16(6), 387-395.

29. Dragomir,

V.D.

(2010).

Environmentally sensitive disclosures and financial performance in a European setting. Journal of Accounting \& Organizational Change, 6(3), 359-388.

30. Dragutinović-Mitrović, S. (2002). Analiza panel serija. Zadužbina Andrejević, Biblioteka Academia, Beograd.

31. Edgar, J., ColwellM, L., Mitchell, S. (2002). Environmental Social Responsibility: The Reality and Rewards of Corporate Citizenship. Paper presented at the SPE International Conference on Health, Safety and Environment in Oil and Gas Exploration and Production, Kuala Lumpur, Malaysia, March 2002. https://doi.org/10.2118/74096-MS

32. Ehsan, S., Nazir, M.S., Nurunnabi, M., Khan, Q.R., Tahir, S., Ahmed, I. (2018). A Multimethod Approach to Assess and Measure Corporate Social Responsibility Disclosure and
Practices in a Developing Economy. Sustainability, 10, 1-18.

33. Emtairah, T., Hansson, L., Hao, G. (2005). Environmental Challenges and Opportunities for Banks in China. Greener Management International, 50, 85-95.

34. Evangelinos, K. I., Skouloudis, A., Nikolaou, I. E., Filho, W. L. (2009). An analysis of corporate social responsibility (CSR) and sustainability reporting assessment in the Greek banking sector. In S. O. Idowu \& W. L. Filho (Eds.), Professionals' perspectives of corporate social responsibility ( $157-$ 177). London, New York: Springer.

35. Fifka, M.S. (2013). Corporate responsibility reporting and its determinants in comparative perspective - A review of the empirical literature and a meta-analysis. Business Strategy and the Environment, 22(1), 1-35.

36. Folger-Laronde, Z., Weber, O. (2018). Climate Change Disclosure of the Financial Sector. CIGI Papers No. 190, 1-17.

37. Fry, F., Hock, R. J. (1976). Who claims corporate responsibility? The biggest and the worst. Business and Society Review/Innovation, 18, 62-65.

38. Gilbert, R. A., Wheelock, D. C. (2007). Measuring commercial bank profitability: Proceed with caution. Federal Reserve Bank of St. Louis Review, 89(6), $515-532$.

39. Goddard, J. A., Molyneux, P. M., Wilson, J. O. S. (2004). Dynamics of Growth and Profitability in Banking. Journal of Money, Credit and Banking, 36(6), 1069-1090.

40. Gray, R., Owen, D., Maunders, K. (1988). Corporate Social Reporting: Emerging Trends in Accountability and the Social Contract. Accounting, 


\section{Journal of Contemporary Management Issues}

Auditing \& Accountability Journal, 1(1), 6-20.

41. Griffin, J.J., Mahon, J.F. (1997). The Corporate Social Performance and Corporate Financial Performance Debate: Twenty-Five Years of Incomparable Research. Business \& Society, 36, 5-31.

42. Guthrie, J., Abeysekera, I. (2006). Content analysis of social, environmental reporting: What is new? Journal of Human Resource Costing \& Accounting, 10(2), 114-126.

43. Guthrie, J., Parker, L.D. (1990). Corporate social disclosure practice: A comparative international analysis. Advances in Public Interest Accounting, 3, 159-175.

44. Hart, S.L. (1995). A Natural-ResourceBased View of the Firm. Academy of Management Review, 20(4), 986-1012.

45. Harte, G., Owen, D. (1991). Environmental Disclosure in the Annual Reports of British Companies: A Research Note. Accounting, Auditing \& Accountability Journal, 4(3), https://doi. org/10.1108/09513579110144442.

46. Hirigoyen, G., Poulain-Rehm, T. (2015). Relationships between Corporate Social Responsibility and Financial Performance: What is the Causality? Journal of Business and Management, 4(1), 18-43.

47. Hopkins, W. E., Hopkins, S. A. (1997). Strategic Planning-Financial Performance Relationships in Banks: A Causal Examination. Strategic Management Journal, 18(8), 635-652.

48. Islam, S., Hosen, A. and Islam, M. (2005). An examination of corporate environmental disclosure by the Bangladeshi public limited companies.
Pakistan Journal of Social Science, 3(9), 1095-1102.

49. Jain, A., Keneley, M., Thomson. D. (2015). Voluntary CSR disclosure works! Evidence from Asia-Pacific banks. Social Responsibility Journal, 11(1), 2-18.

50. Jewell, J.J., Mankin, J.A. (2011). What is your ROA? An investigation of the many formulas for calculating return on assets. Academy of Educational Leadership Journal, Vol. 15, Special Issue, 79-91.

51. Kaium Masud, A., Mi Bae, S., Dae Kim, J. (2017). Analysis of Environmental Accounting and Reporting Practices of Listed Banking Companies in Bangladesh. Sustainability, 9, 1-19.

52. Kamla, R. (2007). Critically approaching social accounting and reporting in the Arab Middle East: a postcolonial perspective. Advances in International Accounting, 20, 105-170.

53. Khan, B., Tariq, R. (2017). Corporate Social Responsibility Impact on Financial Performance of Islamic and Conventional Banks: Evidence from Asian Countries. Research Journal of Finance and Accounting, 8(7), 20-28.

54. Khan, M.H.U.Z., Halabi, A.K. and Samy, M. (2009). CSR reporting practice: A study of selected banking companies in Bangladesh. Social Responsibility Journal, 5(3), 43-57.

55. Kilic, M. (2015). Online corporate social responsibility (CSR) disclosure in the banking industry: Evidence from Turkey. International Journal of Bank Marketing, 34(4), 550-569.

56. Kilic, M., Kuzey, C. (2019). The effect of corporate governance on carbon emission disclosures: Evidence from Turkey. International Journal 
Management, Vol. 26, 2021, No. 2, pp. 115-144

A. Hanić, O. Jovanović, S. Stevanović: ENVIRONMENTAL DISCLOSURE PRACTICE ...

of Climate Change Strategies and Management, 11(1), 35-53.

57. Knezevic, A., Dobromirov, D. (2016). The determinants of Serbian banking industry profitability. Ekonomska Istraživanja / Economic Research, 29(1), 459-474.

58. Knežević, G., Mijoković, M. (2017). Sustainability reporting of listed companies on the Belgrade Stock Exchange. In FINIZ 2017 - Challenges in modern corporate governance, Belgrade, Singidunum University, Serbia, 30-35.

59. Knežević, G., Pavlović, V., Stevanovic, S. (2018). Upgrading Waste Management and Sustainability Reporting in Banking Industry Evidence from Serbia. Industrija, 46(3), https://doi.org/10.5937/ industrija46-17380.

60. Knežević, G., Pavlović, V., Stevanović, S. (2017). Izveštavanje o održivom razvoju - karakteristike, ograničenja i perspektiva u Republici Srbiji. Poslovna ekonomija, 11(1), 83-102.

61. Kontić, Lj., Kontić, J. (2012). Sustainability and Readiness for Change: Insights from a Banking Case Study in Serbia. Amfiteatru Economic, 14(32), 537-548.

62. KPMG. (2017). KPMG International Survey of Corporate Responsibility. The Netherlands.

63. KPMG. (2021). Climate disclosures within the Annual Financial Reports of Banks (Phase 1). UK.

64. Krasodomska, J. (2015). CSR disclosures in the banking industry. Empirical evidence from Poland. Social Responsibility Journal, 11(3), 406-423.

65. Krooss, E.H. (1970). Executive Opinion: What Business Leaders Said and Thought on Economic Issues, 1920's-1960's. New York: Doubleday $\&$ Co.

66. Kundid, A. (2012). Društveno odgovorno poslovanje banaka u Republici Hrvatskoj. Ekonomska misao i praksa, 2, 497-528.

67. Levkov, N., PalamidovskaSterjadovska, N. (2019). Corporate social responsibility communication in Western Balkans banking industry: A comparative study. Management Research and Practice, 11(3), 18-30.

68. Mallin, C., Farag, H. and Ow-Yong, K. (2014). Corporate social responsibility and financial performance in Islamic banks. Journal of Economic Behavior and Organization, Vol. 103, S21-S38.

69. Mallin, C., Farag, H., Ow-Yong, K. (2014). Corporate social responsibility and financial performance in Islamic banks. Journal of Economic Behavior and Organization, 103, S21-S38.

70. Margolis, J.D., Walsh, J.P. (2003). Misery Loves Companies: Rethinking Social Initiatives by Business. Administrative Science Quarterly, 48(2), 268-305.

71. Matuszak, L., Rozanska, E. (2017). An Examination of the Relationship between CSR Disclosure and Financial Performance: The Case of Polish Banks. Journal of Accounting and Management Information Systems, 16(4), 522-533.

72. Matuszak, L., Różańska, E., Macuda, M. (2019). The impact of corporate governance characteristics on banks' corporate social responsibility disclosure. Evidence from Poland. Journal of Accounting in Emerging Economies, 9(1), 75-102.

73. Md Zaini, S., Samkin, G., Sharma, U., Davey, H. (2018). Voluntary disclosure 


\section{Journal of Contemporary Management Issues}

in emerging countries: a literature review. Journal of Accounting in Emerging Economies, 8(1), 29-65.

74. Mijatović, I.S., Stokić, D. (2009). The Influence of Internal and External Codes on CSR Practice: The Case of Companies Operating in Serbia. Journal of Business Ethics, 94, 533-552.

75. Milne, M. J., Adler, R.W. (1999). Exploring the reliability of social and environmental disclosures content analysis. Accounting, Auditing \& Accountability Journal, 12(2), 237-256.

76. Mladenović, Z., Petrović, P. (2007). Uvod u ekonometriju. Ekonomski fakultet Univerziteta u Beogradu.

77. Moskowitz, M. (1972). Choosing socially responsible stocks. Business and Society Review, 1, 71-75.

78. Newberry, S. (2015). Public sector accounting: shifting concepts of accountability. Public Money \& Management, 35(5), https://doi.org/10.1080/095 40962.2015.1061180.

79. Nieto, M. (2017). Banks and Environmental Sustainability: Some Financial Stability Reflections. International Research Centre on Cooperative Finance. Available at SSRN: https://ssrn.com/ abstract $=3082107$

80. Novokmet Kundid, A., Rogošić, A. (2016). Bank sustainability reporting within the GRI-G4 framework. Zeszyty Teoretyczne Rachunkowości, 88(144), 109-123.

81. Orazalin, N., Mahmood, M. (2019). The financial crisis as a wake-up call: corporate governance and bank performance in an emerging economy. Corporate governance, 19(1), 80-101.
82. Orlitzky, M., Schmidt, F. L., Rynes, S.L. (2003). Corporate Social and Financial Performance: A Meta Analysis. Organization Studies, 24(3), 403-441.

83. Owen, D.L., O'Dwyer, B. (2008). Corporate Social Responsibility: The Reporting and Assurance Dimension. In Crane, A., McWilliams, A., Matten, D., Moon, J., Siegel, D. (Eds.). The Oxford handbook of corporate social responsibility. New York: Oxford University Press.

84. Panwar, R., Paul, K., Nybakk, E., Hansen, E., Thompson, D. (2012). The Legitimacy of CSR Actions of Publicly Traded Companies Versus Family-Owned Companies. Journal of Business Ethics, 125(3), 481-496.

85. Parker, L.D. (2011). Twenty-one years of social and environmental accountability research: A coming of age. Accounting Forum, 35(1), 1-10.

86. Pervan, I., Horak, H., Vasilj, M. (2010). Financial reporting regulation for the listed companies: analysis for selected Eastern European transitional countries in the process of EU enlargement. Economic Thought and Practice, 19(2), 277-309.

87. Pivac, S., Vuko, T., Čular, M. (2017). Analysis of annual report disclosure quality for listed companies in transition countries. Ekonomska Istraživanja / Economic Research, 30(1), 721-731.

88. Platonova, E., Asutay, M., Dixon, R., \& Mohammad, S. (2016). The Impact of Corporate Social Responsibility Disclosure on Financial Performance: Evidence from the GCC Islamic Banking Sector. Journal of Business Ethics, 151(2), 451-471.

89. Preston, L.E., O'Bannon, D.P. (1997). The corporate social-financial 
Management, Vol. 26, 2021, No. 2, pp. 115-144

A. Hanić, O. Jovanović, S. Stevanović: ENVIRONMENTAL DISCLOSURE PRACTICE ...

performance relationship: A typology and analysis. Business and Society, 36, 419-429.

90. Rabun, T.M., Williams, C.W. (1974). Social Accounting: The Accountant's Role. Federal Accountant, 3-8.

91. Reger, R. K., Duhaime, I. M., Stimpert, J. L. (1992). Deregulation, Strategic Choice, Risk and Financial Performance. Strategic Management Journal, 13(3), 189-204.

92. Rogošić, A. (2014). Corporate social responsibility reporting of the banks in Bosnia and Herzegovina, Croatia and Montenegro. Theoretical and Applied Economics, 21(9), 71-82.

93. Sapkauskiene, A., Leitoniene, S. (2014). Corporate social responsibility research methods analysis. European Scientific Journal, 1, 237-244.

94. Simpson, G., Kohers, T. (2002). The link between corporate social and financial performance: Evidence from the banking industry. Journal of Business Ethics, 35, 97-109.

95. Stanisavljević, M. (2017). The Analysis of CSR Reports of Serbian Companies. In: Proceedings of the ENTRENOVA - ENTerprise REsearch InNOVAtion Conference, 3, 373-380.

96. Stemler, S. (2001). An Overview of Content Analysis. Practical Assessment, Research \& Evaluation, 7(17), 1-6.

97. Stevanović S., Belopavlović G., Lazarević - Moravčević M. (2014). Obelodanjivanje informacija o zaštiti životne sredine: praksa u Srbiji, Ecologica, 21(76), 679-683.

98. Stevanović S., Belopavlović G., Lazarević - Moravčević M. (2016). Nacionalno računovodstvo zaštite životne sredine: praksa u Srbiji, Ecologica, 23(83), 606-609.
99. Stevanović, S. (2018). Izveštavanje o zagađenju životne sredine: praksa velikih zagađivača i preduzeća $u$ Novom Sadu, in Pravni $i$ ekonomski aspekti primene principa zagađivač plaća. Belgrade: Institute of Economic Sciences.

100.Stevanović, S., Jovanović, O., Hanić, A. (2019). Environmental and Financial Performance: Review of Selected Studies. Economic Analysis, 52(2), 113-127.

101.Stojanović-Aleksić, V., Erić-Nielsen, J., Bošković, A. (2016). Društvena odgovornost $\mathrm{u}$ bankarskom sektoru: iskustva iz Republike Srbije. Bankarstvo, 45(2), 34-55.

102. Stolowy, H., Paugam, L. (2018). The expansion of non-financial reporting: An exploratory study. HEC Paris Research Paper No. ACC-2018-1262, 1-35.

103.Sućeska, M., Hanić, A. (2012). Zakonska regulativa zaštite životne sredine, prirodnih i zajedničkih dobara $\mathrm{u} \mathrm{BiH}$ i njena usaglašenost sa regulativom EU. In: Ekonomski aspekti ekološke politike. Institut ekonomskih nauka; Beogradska bankarska akademija, Beograd, 241-255.

104. Škarić-Jovanović, K. K. (2013). Finansijsko izveštavanje o ulaganjima u zaštitu životne sredine, Acta Economica, 11(18), 83-104.

105.Vićentijević, K., Petrović, Z. (2017). Nefinansijsko izveštavanje u kontekstu zaštite životne, 561-567.

106. Vlastelica Bakić, T., Mijatović, I., Marinović, N. (2016). Key CSR Initiatives in Serbia: A New Concept with New Challenges. In: Idowu S. (eds) Key Initiatives in Corporate Social Responsibility. CSR, Sustainability, Ethics \& Governance. 


\title{
Journal of Contemporary Management Issues
}

107. Vourvachis, P., Wodward, T. (2015). Content analysis in social and environmental reporting research: Trends and challenges. Journal of Applied Accounting Research Forthcoming, 2, 1-25.

108. Wang, R., Wang, X. (2015). What determines the profitability of banks? Evidence from the US. Master Thesis.

109. Warren, R.C. (2003). The evolution of business legitimacy. European Business Review, 15(3), 153-163.
110. Weber, O. (2014). The financial sector's impact on sustainable development. Journal of Sustainable Finance \& Investment, 4(1), 1-8.

111. Wilcox, J. W. (1984). The P/B-ROE Valuation Model. Financial Analysis Journal, 58-66.

112. Williamson, D., Lynch-Wood, G., \& Ramsay, J. (2006). Drivers of environmental behaviour in manufacturing SMEs and the implications for CSR. Journal of Business Ethics, 67(3), 317

\section{PRAKSA IZVJEŠTAVANJA O OKOLIŠNIM UČINCIMA BANKARSKOG SEKTORA U SRBIJI}

\begin{abstract}
Sažetak
U ovom se radu analizira praksa izvještavanja o okolišnim učincima u bankarskom sektoru u Srbiji, utvrđuje izvješćuju li o navedenom u većoj mjeri velike, odnosno sistemski značajne banke te analizira postojanje pozitivnog odnosa između prakse društvene odgovornosti banaka i njihovih financijskih performansi. Za mjerenje performansi izvještavanja o okolišu u bankarskom sektoru u Srbiji koristi se indeks okolišnog izvještavanja, sastavljen od 15 varijabli. Do podataka se došlo analizom sadržaja godišnjeg i okolišnih izvješća za ukupno deset banaka, od kojih su pet klasificirane kao sistemski značajne, u periodu 2015-2019. Uzorak je bio određen raspoloživošću izvješća u analiziranom periodu, kao i godinom osnivanja banke. Rezultati pokazuju da većina (74\%) srpskih banaka izvješćuju o svojim okolišnim politikama, aktivnostima u lokalnoj zajednici (51\%) te učinkovitosti korištenja vode, energije i papira (48\%). Iako rezultati ukazuju da se praksa izvještavanja o okolišnim učincima povećava u bankama u Srbiji, rezultati nisu standardizirani. Nadalje, sistemski značajne banke u Srbiji nemaju bolju praksu izvještavanja. Ekonometrijska analiza pokazuje da status banke ne utječe na njezinu praksu okolišnog izvještavanja, kao i da ne postoji pozitivan odnos između financijskih performansi (mjerenih pokazateljima ROA i ROE) te indeksa okolišnog izvještavanja. Ovaj rad ima implikacije za donositelje javnih politika i računovodstvena tijela u Srbiji, kako bi se standardiziralo nefinancijsko izvještavanje i donijele određene smjernice za ekološki prihvatljivo i održivo bankarstvo.
\end{abstract}

Ključne riječi: okolišno izvještavanje, bankarski sektor, analiza sadržaja, Srbija 